\title{
RELATIONSHIP BETWEEN ENVIRONMENTAL FACTORS AND PERSONAL HYGIENE WITH DIARRHEA AMONG CHILDREN UNDER FIVE IN WEST KOTAWARINGIN, CENTRAL KALIMANTAN
}

\author{
Dortua Lince Sidabalok'), Samsudin²), I Made Djaja3) \\ 1)Masters Program in Environmental Health, Faculty of Public Health, \\ Universitas Indonesia \\ 2)School of Health Sciences, Borneo Cendekia Medica \\ 3)Department of Environmental Health, Faculty of Public Health, Universitas Indonesia
}

\begin{abstract}
Background: Globally, nearly 1 million children die each year because of diarrhea. Diarrhea is a major public health problem in developing countries, including Indonesia. The occurrence of diarrhea has been known to be linked with poor hygiene and sanitation. This study aimed to determine the relationship between environmental factors and personal hygiene with diarrhea among children under five in West Kotawaringin, Central Kalimantan.

Subjects and Method: This was a cross-sectional study conducted at West Kotawaringin, Central Kalimantan. A total of 1.007 households with children under five was selected for this study. The dependent variable was diarrhea. The independent variables were access to drinking water, latrine ownership, type of latrine, environmental hygiene, children defecation habit, and disposing of children feces habit. The data were collected by a set of questionnaire and analyzed by multiple logistic regression

Results: The risk of diarrhea increased with absence of latrine ownership (OR=1.93; 95\%CI=1.28 to 2.91; $\mathrm{p}=0.002)$, sub-standard type of latrine $(\mathrm{OR}=1.88 ; 95 \% \mathrm{CI}=1.27$ to $2.78 ; \mathrm{p}=0.002)$, poor child defecation habit $(\mathrm{OR}=1.85 ; 95 \% \mathrm{CI}=1.26$ to $2.71 ; \mathrm{p}=0.002)$, and free disposal of child feces $(\mathrm{OR}=1.72$; $95 \% \mathrm{CI}=1.28$ to $2.91 ; \mathrm{p}=0.007)$.

Conclusion: The risk of diarrhea increases with absence of latrine ownership, sub-standard type of latrine, poor child defecation habit, and free disposal of child feces.
\end{abstract}

Keywords: diarrhea, hygiene, behavior, environment, children under five

\section{Correspondence:}

Dortua Lince Sidabalok. Masters Program in Environmental Health, Faculty of Public Health, Universitas Indonesia, Depok, West Java. Email: lincebalok4th@gmail.com_Mobile: o81361218156.

\section{BACKGROUND}

Diarrhea is a major cause of morbidity and malnutrition in children under five and is the second leading cause of death after pneumonia (WHO, 2017).

UNICEF records about $8 \%$ of all underfive deaths caused by diarrhea in 2016 and according to WHO there are almost 1.7 billion cases of diarrheal disease occurring in children which causes the death of around 525,000 children under five each year (UNICEF, 2018; WHO, 2017).

The highest burden of death from diarrheal disease in children is concentrated in several developing countries. Seventy-two percent of them occur in 15 countries which only constitute $55 \%$ of the population of children under five in the world, where one of them is Indonesia, which is under Ethiopia in 7 th out of 15 countries that contribute greatly to under-five mortality due to pneumonia and diarrhea (IVAC, 2016).

In Indonesia, diarrhea is an endemic disease with potential outbreaks (extraordinary events) which is often accompanied by death. In 2018, the coverage of diarrhea sufferers in children under five was 40.90\%, 10 times there was an outbreak of diarrhea, which was spread in 8 districts with a case 
fatality rate when the outbreak was $4.76 \%$. This figure is the highest CFR in the last 10 years since 2008, where CFR is expected when outbreaks of diarrhea $<1 \%$ (Ministry of Health, 2019a). Based on data from the District Health Office of Kotawaringin Barat (2019), there was no outbreak of diarrhea in Kotawaringin Barat District in 2018, but the coverage of diarrhea sufferers in infants was found to be almost the same as the national rate, which was $40.4 \%$ with the morbidity of diarrhea in under-five years. 2017 at 843 per 1.000 children under five.

The etiology of diarrheal disease can be caused by various agents including viruses, pathogenic bacteria and parasites which generally occur in the form of gastroenteritis by pathogenic bacterial infections (UNICEF, 2018). Several factors that contribute to the incidence of diarrhea in children based on epidemiological studies of the disease show a complex and varied relationships and influences between variables of environmental factors, hygiene behavior, socio-economic, with the main causes namely various pathogenic organisms, viruses, and parasites (Mengistie et al., 2013; Mokomane et al., 2018). Therefore study in different environments and regions can produce different intervention priorities according to the context of the region (Chopra et al., 2013).

Prevention methods that can be carried out include immunization, safe drinking water, good environmental hygiene and sanitation, proper disposal of human waste, including children's waste, is very important to stop the spread of diarrheal disease in children and adults (UNICEF, 2018). The purpose of this study was to see how the relationship between environmental factors and hygiene behavior towards the incidence of diarrhea in toddlers in West Kotawaringin Regency in 2017.

\section{SUBJECTS AND METHOD}

\section{Design of the Study}

This study was a quantitative study using cross-sectional study design in analyzing both independent and dependent variables which were carried out at a time together or at the same time (Notoatmodjo, 2012). Data were obtained through structured interviews and observations using environmental health risk assessment study questionnaires. Respondents in the study numbered 2,800 households obtained through a multistage random sampling method in 70 villages in the Kotawaringin Barat in 2017 (AMPL Working Group, 2017). Then 1.007 households that had children under five are used as samples in this study.

\section{Variable of the Study}

The independent variables studied were environmental factors such as access to drinking water, family latrines ownership, types of latrines used, environmental hygiene, and hygiene behavioral factors such as children's bowel habits and habit of disposing of children's feces. They were related to the dependent variable namely the incidence of diarrhea in children under five. Analysis of the results of study using the chi-square test with $\alpha=0.005$ and 95\% confidence interval, and multivariate analysis using multiple logistic regression.

\section{RESULTS}

Of the 1.007 households sampled in this study, the incidence of diarrhea in children under five was experienced by 119 households (11.8\%).

Table 1 shows that $14.1 \%$ of households had access to unsafe drinking water, 22.9\% did not have family latrines, $69.8 \%$ used types of latrines that did not meet health requirements, and $86.3 \%$ had dirty environmental conditions. Based on hygiene behavior, it was found that $39.6 \%$ of children under five had the habit of open defecation, and $42.7 \%$ of parents of children under five 
had the habit of disposing of children's feces carelessly. The distribution of the proportion of diarrheal events in children under five based on environmental factors and hygiene behavior is shown next in table 2 .

Table 1. Distribution of respondents based on environmental factors and community hygiene behavior in West Kotawaringin in 2017

\begin{tabular}{lcc}
\hline \multicolumn{1}{c}{ Variable } & $\begin{array}{c}\text { Frequency } \\
(\mathbf{n = 1 0 0 7 )}\end{array}$ & Percetage (\%) \\
\hline $\begin{array}{l}\text { Diarrhea in children under five } \\
\text { Diarrhea }\end{array}$ & 119 & 11.8 \\
No diarrhea & 888 & 88.2 \\
Access to drinking water & 142 & 14.1 \\
Not safe & 865 & 85.9 \\
Secure & & \\
Family latrine ownership & 231 & 22.9 \\
No & 776 & 77.1 \\
Yes & & 69.8 \\
Latrine type & 694 & 31.1 \\
Do not meet the requirements & 313 & 86.3 \\
Meet the requirements & & 13.7 \\
Environmental Hygiene & 869 & \\
Dirty & 138 & 39.6 \\
Clean & & 60.4 \\
Children's bowel habit & 399 & \\
Open defecation & 608 & 42.7 \\
In toilet & & 57.3 \\
Habit of disposing of children's feces & 430 & \\
Open defecation & 577 & \\
In toilet & & \\
\hline
\end{tabular}

Based on Table 2, it is known that the ownership of family latrines and the type of latrines used had a significant association with the incidence of diarrhea in children under five with a $p$ value of 0.002 , respectively. It can be interpreted that children under five who come from families who do not have latrines, have the opportunity to experience diarrhea 2 times more often than children under five who come from families that have latrines.
Children under five from families who use latrines do not meet health requirements had a 2 times greater chance of having diarrhea compared to children under five from families who used latrines meeting health requirements. While in this study, access to drinking water $(\mathrm{p}=1)$ and environmental cleanliness $(\mathrm{p}=0.280)$ were not significantly related to the incidence of diarrhea. 
Table 2. Association between environmental factors and hygiene behavior with the incidence of diarrhea in children under five in Kotawaringin Barat in 2017

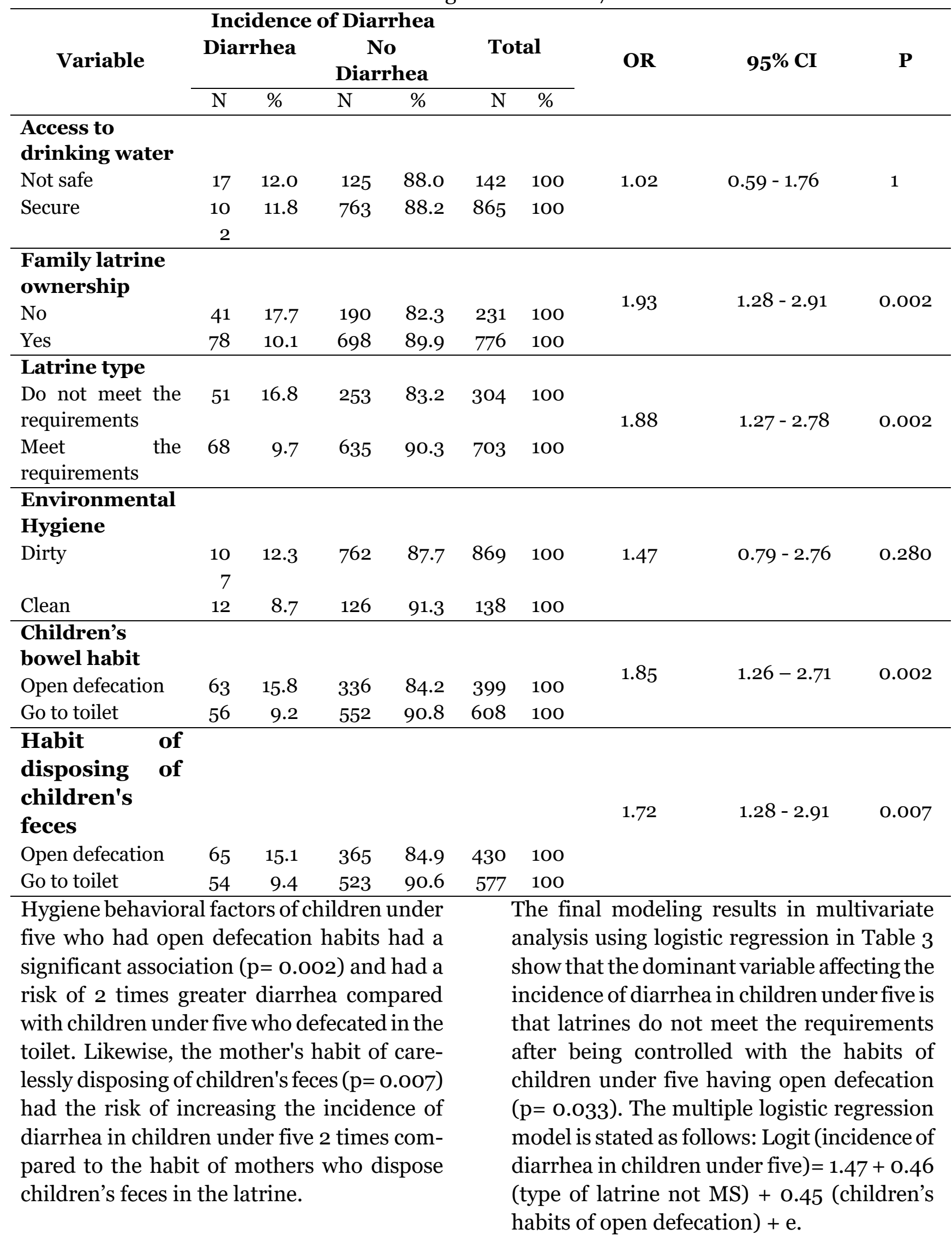


Table 3. Results of the factors logistic regression of modeling related to the incidence of diarrhea in children under five in 2017 in Kotawaringin Barat

\begin{tabular}{lcccc}
\hline \multicolumn{1}{c}{ Variable } & B & $\begin{array}{c}\text { OR } \\
\text { (Exp.B) }\end{array}$ & 95\% CI & P \\
\hline Type of latrine & 0.46 & 1.58 & $1.04-2.41$ & 0.033 \\
Children's bowel habit & 0.45 & 1.57 & $1.04-2.38$ & 0.033 \\
Constant & 1.47 & 4.33 & & 0.0001 \\
\hline
\end{tabular}

\section{DISCUSSION}

The prevalence of diarrheal disease in children under five in this study was $11.8 \%$. This figure is not much different when compared with the reported prevalence of diarrheal disease data in the children under five age category in Kotawaringin Barat in 2018 which was $12.67 \%$ (Health Office, 2019). In line with a study conducted by Suyitno et al. (2019) in Central Kalimantan which found the prevalence of diarrhea in children aged less than two years is $16 \%$. Komarulzaman et al. (2017) also found that the prevalence of diarrhea in children under five by $14.4 \%$ based on data analysis of the Demographic and Health Survey in Indonesia in 2007 2012.

Access to safe drinking water sources is one of the key ways to prevent diarrheal diseases (WHO, 2017). The results showed that 865 families $(85.9 \%)$ of the total respondents had access to safe drinking water sources. It was found that there was no significant difference between the prevalence of diarrhea in the group of households that had safe and unsafe drinking water access. This result is different from the findings of Godana and Mengiste (2013) which stated that unsafe access to drinking water sources is associated with diarrhea $(\mathrm{AOR}=1.98, \mathrm{CI}$ : 1.16-2.23). This might be due to the fact that most of the respondents in the study had access to piped water provided by the West Kotawaringin Regional Drinking Water Company (PDAM). So that the variable access to safe drinking water tended to be homo- geneous. The incidence of diarrhea in children under five in this case may not only related to drinking water, but also related other factors such as dirty environment, transmission through fecal-oral, handling / processing food and beverages or the process of preparing milk that is less hygienic (Agustina et al., 2013; Gibson et al., 2017; Suyitno et al., 2019).

The ownership of family latrine facilities and the types of latrine facilities that meet the requirements are supporting factors for the community not to defecate carelessly and this can make it possible to reduce the incidence of diarrhea. In this study, latrine ownership $(\mathrm{OR}=1.93 ; 95 \% \mathrm{CI}=1.28$ to 2.91 ; $\mathrm{p}=0.002$ ) had a significant association with the incidence of diarrhea. This also supports the study of Fuller et al. (2014) who analyzed Demographic and Health Surveys data from 51 countries, and Baker et al. (2016) which stated that sharing sanitation is associated with an increase in the prevalence of diarrhea in children under five in most countries and appears to be a risk factor for diarrhea for children aged $<5$ years. Similarly, what happened in Amazon, where increased ownership of latrine in homes and increased latrine quality into ceramics was followed by a significant decrease in the number of families who defecated carelessly, or who use neighborhoods' latrines, which had an impact on reducing the prevalence of diarrheal disease from $45.1 \%$ to $35.4 \%$ from 2005 to 2012 (Imada et al., 2016).

The type of latrine used by the family 
was also found to have a significant relationship with the incidence of diarrhea in infants $(\mathrm{OR}=1.88$; $95 \% \mathrm{CI}=1.27$ to 2.78 ; $\mathrm{p}=$ 0.002). Similar results with previous studies conducted by Suyitno et al. (2019) found that children with poor sanitation facilities almost twice had diarrhea than those who had good sanitation facilities $(\mathrm{OR}=1.69 ; 95 \% \mathrm{CI}=1.03$ to 2.77 ).

Variable ownership of family latrines and types of latrines that meet the requirements can be important factors to prevent the occurrence of diarrhea, therefore the community needs to be assisted and empowered to build and own a family latrine, improve the quality of latrine facilities owned, and reduce the use of public latrines.

Environmental hygiene in this case due to littering can attract insects and disease vectors present and multiply then the vector can bring pathogenic bacteria to pollute water and food. In this study the presence of garbage in a dirty environment did not have a significant difference with the incidence of diarrhea.

This was also found in a study conducted by Arimbawa et al. (2016) which stated that landfills are not associated with the incidence of diarrhea in children under five $(\mathrm{p}=0.303)$. Unlike the case with Mengistie et al. (2013) which stated that children in households that throw garbage around the house have a 2.22 times higher chance of experiencing diarrhea compared to children in households who throw garbage in landfills $(\mathrm{OR}=2.22 ; 95 \% \mathrm{CI}=1.20$ up to 4.03$)$

The habit of children who practice open defecation is quite large, which is $39.6 \%$ when compared to the population data that has access to healthy latrines in West Kotawaringin District which has recorded 87.7\% (Ministry of Health, 2019b). The possibility of this is quite understandable, because some children under five, especially those who are smaller, have not been and are not accustomed to using their own latrine. So, in this case it requires support and the role of parents to train and accustom children under five to defecate in latrine/toilet.

The habit of children's open defecating $(\mathrm{OR}=1.85 ; 95 \% \mathrm{CI}=1.26$ to 2.72$)$ increases twice as large as the incidence of diarrhea. Because feces in the environment will openly invite flies, and various disease vectors that pose a risk of diarrhea through transmission of fecal-oral pathogenic bacteria. In contrast to a study conducted by Islam et al. (2018) which found that disposing of unsafe baby feces or the presence of human feces in the environment were not related to the incidence of diarrhea in children aged $<3$ years in Bangladesh. The government is essential to be able to pay attention to this because the target of monitoring bowel behavior is always directed at adults. Whereas, human feces both adults and children contaminate the environment in the same way.

In this study, it was found that mothers who had the habit of disposing of children's feces had twice the risk of increasing the incidence of diarrhea in children under five $(\mathrm{OR}=1.72 ; 95 \% \mathrm{CI}=1.28$ to 2.91$)$. The habit of disposing of children's feces in this case is throwing it out, into an open trash bin, left alone in the open, including disposing of a baby's diaper containing feces in it. It is best if the baby's stool is safely disposed of by being disposed of or rinsed in the toilet (WSP, 2015). The results of this study are in line with the results of a study by Cronin A, et al. (2016) which stated that the disposal of unsafe stools of children is strongly associated with an increased likelihood of diarrhea in children (OR: 1.46 ; 95\% CI $=1.18$ to $1.82 ; \mathrm{p}=0.001)$. In India, based on a study by Bawankule et.al (2017), the likelihood of diarrhea in children whose stools are disposed carelessly is estimated to be $11 \%$ higher (95\% CI=1.01 to 121) than children whose 
feces are disposed safely. In that study it was stated that lack of mother's knowledge and limited information about hygiene behavior in the community were one of the causes.

Linda's study (2018) which found a relationship between maternal and toddlers hygiene behavior with the occurrence of diarrhea in Jombang, also supports the explanation that it may be based on lack of knowledge of the mother or caregiver. It is because behavior is affected by knowledge. Hence, it becomes very important to increase knowledge for children and also housewives through health promotion and counseling to safely dispose of children's feces.

\section{CONCLUSION}

Based on the results of the study, it is concluded that not having a family latrine, type of latrine that does not meet the requirements, habits of children open defecating and the habit of disposing children feces carelessly have a significant association with the risk of increasing the incidence of diarrhea in children under five in Kotawaringin Barat. The most dominant factor that affecting is the type of latrine do not meet the requirements after being controlled by the habit of children open defecating.

Cross sectorial strategic efforts are needed to change hygiene behavior in terms of disposing of feces in latrines and improving the quality of family latrine facilities that meet health requirements. Some things that can be recommended related to the results of the study are: 1 ) the importance of health promotion efforts in the community to change open defecation behavior including in children under five; 2) Maternal knowledge is needed to be increased for mothers who have children under five to properly dispose children's feces and not pollute the environment; 3) The importance of increasing access and ownership of latrines that meet the requirements at the household level.

\section{REFERENCES}

Agustina R, Sari TP, Satroamidjojo S, BoveeOudenhoven IMJ, Feskens EJM, Kok FJ (2013). Association of food-hygiene practices and diarrhea prevalence among Indonesian young children from low socioeconomic urban areas. BMC Public Health, 13(977). Retrieved from http://www.biomedcentral.com/14712458/13/977\%oAPage

Arimbawa IW, Dewi KAT , Zakwan bin Ahmad (2016). Hubungan faktor perilaku dan faktor lingkungan terhadap kejadian diare pada balita di Desa Sukawati, Kabupaten Gianyar Bali tahun 2014. Intisari Sains Medis, 6(1): 8-15.

Baker KK, E.O'Reilly C, Levine M M, Kotloff K L, Nataro J P, Ayers T L, et al (2016). Sanitation and hygiene-specific risk factors for moderate-to-severe diarrhea in young children in the global enteric multicenter study, 2007 - 2011 : Casecontrol study. PLOS Medicine, 13(5): 2007-2011. https://doi.org/10.1371/journal.pmed.1002010

Bawankule R, Singh A, Kumar K, Pedgaonkar S (2017). Disposal of children 's stools and its association with childhood diarrhea in India. BMC Public Health, 17: 1-9. https://doi.org/10.1186/s12889-016-3948-2

Chopra M, Mason E, Borrazzo J, Campbell H, Rudan I, Liu L, et al (2013). Ending of preventable deaths from pneumonia and diarrhoea: An achievable goal. The Lancet, 381(9876): 1499-1506. https://doi.org/10.1016/So140-6736(13)60319-O

Cronin AA, Sebayang SK, Torlesse H, Nandy $\mathrm{R}$ (2016). Association of safe disposal of child feces and reported diarrhea in Indonesia : Need for stronger focus on a neglected risk. International Journal of Environmental Research and Public 
Health, 13(310). https://doi.org/10.3390/ijerph13030310

Dinkes (2019). Profil kesehatan Kabupaten Kotawaringin Barat tahun 2018. Pangkalan Bun: Dinas Kesehatan Kabupaten Kotawaringin Barat.

Fuller J A, Clasen T, Heijnen M, Eisenberg J N S (2014). Shared sanitation and the prevalence of diarrhea in young children : Evidence from 51 countries , 2001 -2011. The American Society Of Tropical Medicine and Hygiene, 91(1): 173-180. https://doi.org/10.4269/ajtmh.13-0503

Gibson S, Sahanggamu D, Fatmaningrum D, Curtis V,White S (2017). Unfit for human consumption: A study of the contamination of formula milk fed to young children in East Java, Indonesia. Tropical Medicine and International Health, 22(10): 1275-1282. https://doi.org/10.1111/tmi.12927

Godana W, Mengiste B (2013). Environmental factors associated with acute diarrhea among children under five years of age in derashe district, Southern Ethiopia. Science Journal of Public Health, 1(3): 119-124. https://doi.org/10.11648/j.sjph.20130103.12

Imada KS, Araujo TS de, Muniz PT, Padua VL de (2016). Socioeconomic, hygienic , and sanitation factors in reducing diarrhea in the Amazon. Revista de Saúde Pública, 50(77): 1-10. https://doi.org/10.1590/S1518-8787.2016050006505

Islam M, Ercumen A, Ashraf S, Rahman M, Shoab A K (2018). Unsafe disposal of feces of children $<3$ years among households with latrine access in rural Bangladesh: Association with household characteristics, fly presence and child diarrhea. PLOs One, 13(4): 1-13. https://doi.org/10.1371/journal. pone.0195218\%oAEditor
International Vaccine Access Center (IVAC) (2016). Pneumonia \& diarrhea progress report: Reaching goals through action and innovation. International Vaccine Access Center (IVAC), Johns Hopkins Bloomberg School of Public Health.

Kemenkes RI (2019a). Profil kesehatan Indonesia tahun 2018. Jakarta: Kementerian Kesehatan Republik Indonesia.

Kemenkes RI (2019b). Sanitasi total berbasis masyarakat, lebih bersih lebih sehat. Retrieved on September 10, 2019, from http://monev.stbm.kemkes.go.id/index .php/spanel/pilar_1/kabupaten.

Komarulzaman A, Smits J, Jong E De (2017). Clean water, sanitation and diarrhoea in Indonesia : Effects of household and community factors. Global Public Health, An International Journal for Research, Policy and Practice, 12(9): 1141-1155. https://doi.org/10.1080/17441692.2015.1127985

Linda RE, Nugroho B, A Sestu RD (2018). Hubungan personal hygiene ibu dan balita dengan kejadian diare pada balita di Desa Bareng Kabupaten Jombang. Jurnal Ilmiah Kebidanan (Scientific Journal of Midwifery), 4(1): 45-51. https://doi.org/10.33023/jikeb.v4i1.155

Mengistie B, Berhane Y, Worku A (2013). Prevalence of diarrhea and associated risk factors among children under-five years of age in Eastern Ethiopia: A cross-sectional study. Open Journal of Preventive Medicine, 3(7): 446-453. https://doi.org/10.4236/ojpm.2013.37 o6o Open

Mokomane M, Kasvosve I, Melo E De, Pernica JM, David M (2018). The global problem of childhood diarrhoeal diseases: emerging strategies in prevention and management. Therapeutic Advances in Infectious Disease, 5(1): 29-43. https://doi.org/10.1177/204993 
Notoatmodjo S (2012). Metodologi penelitian kesehatan. Jakarta: Rineka Cipta.

Pokja AMPL (2017). Laporan studi EHRA (environmental health risk assessment) Kabupaten Kotawaringin Barat Provinsi Kalimantan Tengah. Pangkalan Bun: Dinas Kesehatan Kabupaten Kotawaringin Barat.

Suyitno, Chompikul J, Tiraphat S, Anye KS (2019). Prevalence and risk factors for diarrhea among children aged less than two years in Central Kalimantan Province, Indonesia. Journal of Public Health and Development, 17(1): 31-45.
UNICEF (2018). Diarrhoea remains a leading killer of young children, despite the availability of a simple treatment solution. Retrieved from https://dataunicef.org/topic/child-health/diarrhoealdisease/

WHO (2017). Diarrhoeal disease. Retrieved from https://www.who.int/news-room/fact-sheets/detail/diarrhoealdisease

WSP (2015). Scaling up rural sanitation and hygiene management, management of child feces : Current disposal practices. Retrieved from www.wsp.org 